\title{
PENETAPAN RENDEMEN EKSTRAK DAUN JAMBU MAWAR (Syzygium jambos L. Alston) BERDASARKAN VARIASI KONSENTRASI ETANOL DENGAN METODE MASERASI
}

\author{
Eka Siswanto Syamsul $^{1}$, Olanda Anugerah ${ }^{2}$, Risa Supriningrum $^{3}$ \\ ${ }^{1,2,3}$ STIKES Samarinda \\ Email korespondensi: eka8382@gmail.com
}

\begin{abstract}
ABSTRAK
Syzygium jambos (jambu mawar) merupakan tumbuhan yang berkhasiat sebagai obat. Studi ini bertujuan untuk mengetahui pengaruh variasi konsentrasi etanol terhadap rendemen ekstrak daun jambu mawar dengan metode maserasi. Penelitian yang dilakukan adalah penelitian eksperimen. Tahap penelitian meliputi pengumpulan sampel, determinasi, pembuatan simplisia, ekstraksi secara maserasi dengan variasi konsentrasi etanol, penetapan rendemen, skrining fitokimia dan penetapan susut pengeringan. Hasil skrining fitokimia menunjukkan bahwa pada etanol $50 \%$ ekstrak jambu mawar positif mengandung flavonoid, tanin, saponin dan steroid/terpenoid, etanol $70 \%$ dan $90 \%$ positif mengandung flavonoid, tanin dan steroid/terpenoid. Rendemen ekstrak etanol jambu mawar 50\% (23,01\% \pm 0,37), etanol 70\% (21,96\% \pm $1,18)$ dan etanol $90 \%(16,57 \% \pm 0,38)$. Hasil uji LSD menunjukkan perbedaan signifikan $(\mathrm{p}<0,05)$ antara kelompok $90 \%$ dengan $50 \%$ dan $70 \%$.
\end{abstract}

Kata kunci: Jambu mawar, Rendemen, Variasi konsentrasi etanol 


\title{
DETERMINATION OF MAWAR JAMBU LEAF EXTRACT (Syzygium jambos L. Alston) BASED ON VARIATION OF ETHANOL CONCENTRATION WITH THE MASERATION METHOD
}

\begin{abstract}
Syzygium jambos is a medicinal plant. This study aims to determine the effect of variations in ethanol concentration on yield of guava leaf extract by maceration method. The research conducted was experimental research. The research phase includes sample collection, determination, manufacture of simplicia, extraction by maceration with variations in ethanol concentration, determination of yield, phytochemical screening and determination of drying losses. Phytochemical screening results showed that 50\% of ethanol extracts of positive rose guava contained flavonoids, tannins, saponins and steroids / terpenoids, $70 \%$ ethanol and $90 \%$ positives contained flavonoids, tannins and steroids / terpenoids. The yield of rose guava ethanol extract was $50 \%$ (23.01\% \pm 0.37$)$, $70 \%$ ethanol $(21.96 \% \pm 1.18)$ and $90 \%$ ethanol $(16.57 \% \pm$ 0.38). LSD test results showed a significant difference $(p<0.05)$ between the $90 \%$ to $50 \%$ and $70 \%$ groups.
\end{abstract}

Keywords: Syzygium jambos, yield, Ethanol concentration

\section{PENDAHULUAN}

Jambu mawar merupakan salah satu tumbuhan tropis khas Indonesia yang digunakan sebagai obat tradisional yang mengandung senyawa antibakteri. Tumbuhan ini sangat jarang ditemukan dan belum banyak dikenal oleh masyarakat (Mohanty dan Cock, 2010). Rebusan daun jambu mawar dapat digunakan untuk mengatasi diare, sebagai ekspektoran dan mengobati rematik. Jus daun jambu mawar digunakan sebagai obat penurun panas, bubuk daun digunakan untuk menggosok tubuh pasien cacar sebagai pemberi efek pendingin (Morton, 1987).

Daun jambu mawar mengandung beberapa senyawa antibakteri antara lain flavonoid dan tanin (Mamahit dkk., 2016). Kandungan tanin ditemukan sangat tinggi pada kulit batang jambu mawar sebesar 2,5 mg/ml, pada biji 1,9 $\mathrm{mg} / \mathrm{ml}$ sedangkan pada daun $1,4 \mathrm{mg} / \mathrm{ml}$ dalam pelarut aseton (Murugan dkk., 2011). Ekstrak kulit batang, daun dan biji jambu mawar memiliki daya hambat yang baik dalam menghambat pertumbuhan S. Aureus dan E. Coli (Murugan dkk., 2011).

Cairan penyari berpengaruh terhadap kandungan zat aktif dari bahan yang terekstraksi (Turkmen dkk., 2005). Cairan penyari dalam proses pembuatan ekstrak diharapkan adalah pelarut yang baik untuk senyawa kandungan yang berkhasiat atau yang aktif, dengan demikian senyawa tersebut dapat terpisahkan dari bahan dan dari senyawa kandungan lainnya, serta ekstrak hanya mengandung sebagian besar senyawa kandungan yang diinginkan. Cairan penyari yang dipilih 
harus dapat melarutkan hampir semua metabolit sekunder yang dikandung. Faktor utama untuk pertimbangan pada pemilihan cairan penyari adalah selektivitas, kemudahan bekerja, proses dengan cairan tersebut, ekonomis, ramah lingkungan, dan keamanan (Depkes RI, 2000).

Rendemen suatu ekstrak dapat dipengaruhi oleh beberapa faktor salah satunya adalah jenis pelarut dan konsentrasinya. Penelitian yang dilakukan oleh Wardani dan Leviana (2010) mengenai perbandingan rendemen ekstrak daun jambu biji dengan pelarut etanol $50 \%, 70 \%$, dan 90\% menggunakan metode maserasi menunjukkan bahwa terdapat perbedaan rendemen yang dihasilkan yaitu $22,07 \%$, 31,87\%, dan 25,13\%. Mengetahui pengaruh variasi konsentrasi etanol terhadap rendemen ekstrak daun jambu mawar.

\section{METODE PENELITIAN}

Penelitian yang dilakukan adalah penelitian eksperimen. Tahap penelitian ini dimulai dengan pengumpulan sampel, determinasi tumbuhan, pembuatan simplisia, ekstraksi, skrining fitokimia, penetapan susut pengeringan dan penetapan rendemen.

\section{Bahan dan Alat}

Bahan yang digunakan dalam penelitian ini adalah air suling, aluminium foil, amil alkohol, asam asetat anhidrat, etanol $50 \%$, etanol $70 \%$, etanol $90 \%, \mathrm{FeCl}_{3}, \mathrm{HCl}$ pekat, $\mathrm{HCl} 2 \mathrm{~N}$, $\mathrm{H}_{2} \mathrm{SO}_{4}$ pekat, n-heksan, pereaksi bouchardat, pereaksi dragendorf, pereaksi meyer, serbuk $\mathrm{Mg}$, dan simplisia daun jambu mawar.

Alat-alat yang digunakan pada penelitian ini adalah batang pengaduk, blender, cawan porselen, corong buchner, corong gelas, erlenmeyer, gelas kimia, gelas ukur, gunting, kamera, kertas saring, labu ukur, maserator, neraca analitik, penangas air, penjepit kayu, pipet tetes, rak tabung, spatel, tabung reaksi, toples dan vacuum pumps

\section{Tahapan Penelitian}

\section{Pengumpulan sampel}

Sampel yang digunakan adalah daun tua jambu mawar dan dipanen pada sore hari di Kelurahan Loa Bakung Kecamatan Sungai Kunjang Kota Samarinda.

\section{Determinasi Tumbuhan}

Determinasi tumbuhan dimaksudkan untuk mengetahui kebenaran sampel. Determinasi dilakukan di Laboratorium Anatomi dan Sistematika Tumbuhan Fakultas Matematika dan Ilmu Pengetahuan Alam (F-MIPA) Universitas Mulawarman Samarinda.

\section{Pembuatan Simplisia}

Dilakukan pengumpulan daun jambu mawar sebanyak $5 \mathrm{~kg}$ yang diperoleh di kelurahan Loa Bakung Kota Samarinda, kemudian dilakukan sortasi basah untuk memisahkan kotoran-kotoran atau bahan asing yang terdapat di simplisia. Daun jambu mawar selanjutnya dicuci dengan air mengalir, ditiriskan, ditimbang sebagai berat basah kemudian dirajang, 
dikeringkan dengan cara dianginanginkan di udara yang terlindungi oleh sinar matahari langsung setelah itu ditimbang sebagai berat kering, dihaluskan, dan diayak dengan pengayak mesh 60 .

\section{Pembuatan ekstrak}

Ditimbang sebanyak 25 gram serbuk kering daun jambu mawar, serbuk simplisia daun jambu mawar diekstraksi dalam $250 \mathrm{ml}$ menggunakan variasi konsentrasi etanol (50\%, 70\% atau 90\%) dengan metode maserasi. Simplisia di tempatkan dalam wadah kaca sampai seluruh serbuk terendam kemudian diaduk menggunakan mesin pengaduk selama 3 jam replikasi pada masing-masing pelarut dilakukan sebanyak tiga kali kemudian disaring dengan menggunakan corong buchner, filtrat yang diperoleh diuapkan diatas penangas air sampai kental.

\section{Skirining Fitokimia}

Skrining fitokimia dilakukan untuk mengetahui metabolit sekunder yang terkandung di dalam ekstrak daun jambu mawar pada masing-masing konsentrasi etanol. Metabolit sekunder yang diuji secara kualitatif meliputi alkaloid, flavonoid, tanin, saponin dan steroid/terpenoid.

Pembuatan larutan ekstrak daun jambu mawar, mula-mula ektrak kental ditimbang sebanyak 0,5 g kemudian di larutkan dengan masing-masing konsentrasi etanol 50\%, 70\% dan 90\% sebanyak $10 \mathrm{ml}$ di dalam labu ukur 100 hingga larut sempurna, lalu di tambahkan dengan air suling hingga $100 \mathrm{ml}$.

\section{Uji Alkaloid}

a. Pereaksi Mayer

Sepuluh tetes ekstrak dimasukkan ke dalam tabung reaksi, lalu ditambahkan dengan pereaksi mayer sebanyak 2-3 tetes menghasilkan endapan putih kekuningan menunjukkan adanya senyawa alkaloid

b. Pereaksi Bouchardat

Sepuluh tetes ekstrak dimasukkan ke dalam tabung reaksi, lalu ditambahkan dengan pereaksi bouchardat sebanyak 2-3 tetes menghasilkan endapan coklat sampai hitam menunjukkan adanya senyawa alkaloid

c. Pereaksi Dragendrof

Sepuluh tetes ekstrak dimasukkan ke dalam tabung reaksi, lalu ditambahkan dengan pereaksi dragendrof sebanyak 2-3 tetes menghasilkan endapan jingga sampai merah coklat menunjukkan adanya senyawa alkaloid. Hasil uji positif bila terbentuk endapan paling sedikit dua dari tiga percobaan di atas (Syamsul dkk, 2016: Lestari dkk, 2019).

\section{Uji Flavonoid}

Sepuluh tetes ekstrak etanol daun jambu mawar dimasukkan ke dalam tabung reaksi, lalu ditambahkan sebanyak 2 tetes $\mathrm{HCl}$ pekat, lalu dimasukkan serbuk $\mathrm{Mg}$ kemudian ditambahkan amil alkohol. Bila terjadi warna kuning, orange atau merah pada lapisan amil alkohol menunjukkan adanya flavonoid (Syamsul dkk, 2014) 


\section{Tannin}

Sepuluh tetes ekstrak dimasukkan ke dalam tabung reaksi kemudian ditambahkan 2 tetes $\mathrm{FeCl}_{3} 1 \%$. Terjadi warna biru atau hijau kehitaman menunjukkan adanya senyawa tanin. (Syamsul dkk, 2014)

\section{Uji Saponin}

Sepuluh tetes ekstrak dimasukkan ke dalam tabung reaksi kemudian ditambahkan $10 \mathrm{ml}$ air panas, didinginkan kemudian dikocok kuatkuat selama 10 detik, busa yang stabil akan terus terlihat selama 5 menit dan tidak hilang pada penambahan 1 tetes larutan $\mathrm{HCl} 2 \mathrm{~N}$, apabila busa tidak hilang menunjukkan adanya saponin (Supomo dkk., 2016)

\section{Uji Steroid/Terpenoid}

0,5 gram ekstrak daun jambu mawar dimaserasi dengan $10 \mathrm{ml} \mathrm{n}$ heksan selama 2 jam, disaring, filtrat diuapkan dan sisanya ditambahkan pereaksi asam asetat anhidrat dan asam sulfat pekat. Jika terbentuk warna ungu atau merah yang berubah menjadi biru ungu atau biru kehijauan menunjukkan adanya steroid/terpenoid (Supomo dkk., 2016).

\section{Penentuan Kadar Air (Metode Gravimetri)}

Sampel ditimbang sebanyak 1 gram di dalam cawan yang telah diketahui beratnya, kemudian dikeringkan dalam oven suhu $105^{\circ} \mathrm{C}$ selama 30 menit, setelah itu didinginkan dalam desikator selama 15 menit dan ditimbang hingga bobot tetap. Kadar air dihitung dengan rumus sebagai berikut :

$$
\begin{gathered}
\% \text { Susut Pengeringan }=\frac{b-(c-a)}{b} \times 100 \% \\
\text { Keterangan }: \mathrm{b}=\text { Berat sampel }(\mathrm{gram}) \\
\mathrm{c}=\text { Berat cawan }+ \text { sampel }(\mathrm{gram}) \\
\mathrm{a}=\text { Berat cawan (Depkes RI, 2000) }
\end{gathered}
$$

\section{Perhitungan Rendemen}

$$
\% \text { Rendemen }=\frac{\text { bobot ekstrak } \text { kental }(\mathrm{gram})}{\text { bobot simplisia awal }(\mathrm{gram})} \times 100 \% \quad(\text { Depkes RI , 2000) }
$$

Analisis Data

Analisis data yang digunakan dalam penelitian ini adalah analisis deskriptif dan diolah dengan perangkat SPSS uji One Way Anova dengan Uji Least Significence Different (LSD) berupa data mengenai rendemen ekstrak daun jambu mawar yang didasarkan pada data hasil penelitian masingmasing konsentrasi etanol dengan menggunakan metode maserasi. (Syamul dan Lestari, 2020)

\section{HASIL DAN PEMBAHASAN}

\section{Determinasi Tanaman}

Hasil determinasi di Laboratorium Fisiologi Fakultas Matematika dan Ilmu Pengetahuan Alam Universitas Mulawarman Samarinda menyatakan bahwa sampel yang digunakan adalah 
daun jambu mawar dari spesies Syzygium jambos (L.) Alston.

\section{Ekstraksi Simplisia Daun Jambu Mawar}

Pembuatan ekstrak daun jambu mawar menggunakan pelarut etanol $50 \%, 70 \%$ dan $90 \%$ dengan metode maserasi karena metode ini pengerjaannya sederhana dan mudah dilakukan. Selama maserasi atau proses perendaman dilakukan pengadukan selama 3 jam menggunakan maserator upaya ini menjamin keseimbangan konsentrasi bahan ekstraksi yang lebih cepat di dalam cairan serta tetap terjaga adanya derajat konsentrasi yang sekecilkecilnya antara larutan di dalam sel dengan larutan di luar sel. Ekstrak cair yang diperoleh kemudian diuapkan di atas penangas air hingga diperoleh ekstrak kental, kemudian dihitung nilai rendemennya pada tabel 1 berikut :

Tabel 1. Hasil Rendemen Ekstrak Daun Jambu Mawar

\begin{tabular}{cccc}
\hline Konsentrasi Etanol & $\begin{array}{c}\text { Ekstrak } \\
(\mathbf{g r a m})\end{array}$ & $\begin{array}{c}\text { Rendemen } \\
(\boldsymbol{\%})\end{array}$ & $\begin{array}{c}\text { Rata-rata } \\
(\boldsymbol{\%}) \pm \mathbf{S D}\end{array}$ \\
\hline $50 \%$ & 5,71 & 22,84 & $23,01 \pm 0,37$ \\
& 5,69 & 22,76 & \\
$70 \%$ & 5,86 & 23,44 & \\
& 5,15 & 20,6 & $21,96 \pm 1,18$ \\
& 5,68 & 22,72 & \\
$90 \%$ & 5,64 & 22,56 & \\
& 4,16 & $16,64^{*}$ & $16,57 \pm 0,38$ \\
& 4,23 & $16,92^{*}$ & \\
\hline
\end{tabular}

Keterangan : * Uji LSD berbeda signifikan dengan kelompok lainnya $(\mathrm{p}<0,05)$

Tabel 1 menunjukkan bahwa ekstrak daun jambu mawar konsentrasi etanol $50 \%$ menghasilkan rendemen lebih banyak dibandingkan konsentrasi etanol $70 \%$ dan 90\%. Hal ini menunjukkan bahwa kandungan senyawa kimia dalam jambu mawar relatif mudah larut dalam etanol yang memiliki konsentrasi paling kecil, dimana pada konsentrasi tersebut terdapat campuran etanol:air 50\%:50\%. Rendemen yang dihasilkan merupakan jumlah senyawa yang terekstrak oleh berbagai macam pelarut dengan tingkat kepolaran yang berbeda (Syahbirini dkk, 2005).

Tabel 1 menunjukkan bahwa hasil uji dari One Way Anova menunjukkan perbedaan yang signifikan antar kelompok perlakuan $(\mathrm{p}<0,05)$. Hasil uji Post Hoc Test dengan metode LSD menunjukkan kelompok ekstrak etanol 90\% memiliki perbedaan signifikan dengan etanol $50 \%$ dan $70 \%(\mathrm{p}<0,05)$ sementara etanol $50 \%$ dan $70 \%$ tidak menunjukkan perbedaan yang signifikan ( $>>0,05)$. Berdasarkan uji statistik tersebut, maka dapat 
disimpulkan bahwa variasi konsentrasi etanol berpengaruh terhadap rendemen ekstrak daun jambu mawar. Perbedaan rendemen ekstrak etanol 50\%, 70\% dan 90\% disebabkan antara lain karena perbedaan kemampuan masing-masing cairan penyari dalam proses ekstraksi untuk memperoleh zat aktif yang terkandung dalam ekstrak tersebut dan kelarutan zat aktif dalam cairan penyari yang berbeda (Wardani dan Leviana, 2010)

\section{Hasil Skrining Fitokimia}

Berdasarkan hasil uji yang telah dilakukan didapatkan hasil skrining metabolit sekunder berdasarkan tabel 2 .

Tabel 2. Hasil Skrining Ekstrak Daun Jambu Mawar Dengan Variasi Konsentrasi Etanol

\begin{tabular}{|c|c|c|c|c|c|c|c|}
\hline $\begin{array}{l}\text { Golongan } \\
\text { Senyawa }\end{array}$ & Pereaksi & Etanol 50\% & Ket & Etanol 70\% & Ket & Etanol 90\% & Ket \\
\hline Alkaloid & $\begin{array}{l}\text { 1.Mayer } \\
\text { 2.Bouchardat } \\
\text { 3.Dragendrof }\end{array}$ & $\begin{array}{l}\text { 1. tidak } \\
\text { terbentuk } \\
\text { endapan } \\
\text { 2. endapan } \\
\text { coklat sampai } \\
\text { hitam } \\
\text { 3. tidak } \\
\text { terbentuk } \\
\text { endapan }\end{array}$ & - & $\begin{array}{l}\text { 1. tidak } \\
\text { terbentuk } \\
\text { endapan } \\
\text { 2. endapan } \\
\text { coklat sampai } \\
\text { hitam } \\
\text { 3. tidak } \\
\text { terbentuk } \\
\text { endapan }\end{array}$ & - & $\begin{array}{l}\text { 1. tidak } \\
\text { terbentuk } \\
\text { endapan } \\
\text { 2. tidak } \\
\text { terbentuk } \\
\text { endapan } \\
\text { 3. tidak } \\
\text { terbentuk } \\
\text { endapan }\end{array}$ & - \\
\hline Flavonoid & $\begin{array}{l}\text { Serbuk Mg, } \\
\mathrm{HCl} \text { pekat, } \\
\text { dan amil } \\
\text { alkohol }\end{array}$ & $\begin{array}{l}\text { warna } \\
\text { kuning, } \\
\text { orange, } \\
\text { merah pada } \\
\text { lapisan amil } \\
\text { alkohol }\end{array}$ & + & $\begin{array}{l}\text { Warna hijau } \\
\text { tua pada } \\
\text { lapisan amil } \\
\text { alhokol }\end{array}$ & + & $\begin{array}{l}\text { Warna hijau } \\
\text { tua pekat } \\
\text { pada lapisan } \\
\text { amil alkohol }\end{array}$ & + \\
\hline Tanin & Air dan $\mathrm{FeCl}_{3}$ & $\begin{array}{l}\text { Warna hijau } \\
\text { kehitaman }\end{array}$ & + & $\begin{array}{l}\text { Warna hijau } \\
\text { kehitaman }\end{array}$ & + & $\begin{array}{l}\text { Warna hijau } \\
\text { kehitaman }\end{array}$ & + \\
\hline Saponin & $\begin{array}{l}\text { Air panas dan } \\
\mathrm{HCl} 2 \mathrm{~N}\end{array}$ & $\begin{array}{l}\text { Terbentuk } \\
\text { busa } \\
\text { permanen }\end{array}$ & + & $\begin{array}{l}\text { Tidak } \\
\text { terbentuk } \\
\text { busa }\end{array}$ & - & $\begin{array}{l}\text { Tidak } \\
\text { terbentuk } \\
\text { busa }\end{array}$ & - \\
\hline $\begin{array}{c}\text { Steroid/Te } \\
\text { rpenoid }\end{array}$ & $\begin{array}{l}\text { n-heksan, } \\
\text { asam asetat } \\
\text { anhidrat, dan } \\
\mathrm{H}_{2} \mathrm{SO}_{4} \text { pekat }\end{array}$ & Warna hijau & + & Warna hijau & + & Warna hijau & + \\
\hline
\end{tabular}

Keterangan :

$+:$ Positif mengandung metabolit sekunder

- : Negatif mengandung metabolit sekunder

Skrining fitokimia terhadap ekstrak dilakukan untuk mendapatkan informasi golongan senyawa metabolit sekunder yang terdapat didalamnya. Tabel 3 menunjukkan bahwa ekstrak etanol $50 \%$ daun jambu mawar 
mengandung senyawa metabolit sekunder flavonoid, tanin, saponin dan steroid/terpenoid, sedangkan ekstrak etanol $70 \%$ dan $90 \%$ daun jambu mawar mengandung senyawa metabolit sekunder flavonoid, tanin dan steroid/terpenoid. Menurut

Harborne (1987) apabila pada saat penambahan pereaksi mayer terbentuk endapan putih atau kuning, pereaksi bouchardat terbentuk endapan coklat sampai hitam, pereaksi dragendrof terbentuk endapan jingga sampai merah coklat menandakan adanya alkaloid. Ekstrak etanol 50\% menghasilkan warna jingga pada lapisan amil alkohol yang berarti mengandung senyawa flavon sedangkan pada ekstrak etanol $70 \%$ dan $90 \%$ menghasilkan warna hijau pada lapisan amil alkohol yang berarti mengandung senyawa glikosida (Marliana dkk., 2005). Perubahan warna terjadi ketika penambahan $\mathrm{FeCl}_{3}$ yang bereaksi dengan salah satu gugus hidroksil pada senyawa tanin, penambahan $\mathrm{FeCl}_{3}$ pada ekstrak menghasilkan warna hijau kehitaman yang menunjukkan adanya senyawa tanin (Sangi dkk., 2008). Pemeriksaan steroid/terpenoid ekstrak membentuk warna hijau kebiruan pada saat penambahan asam asetat anhidrat dan asam sulfat pekat. Menurut Harborne (1987) jika mengandung senyawa steroid/terpenoid apabila ditambahkan asam asetat anhidrat dan asam sulfat pekat akan terbentuk warna hijau atau hijau kebiruan. Saponin merupakan senyawa yang mempunyai gugus hidrofilik dan hidrofob, pada saat digojok gugus hidrofil akan berikatan dengan air sedangkan gugus hidrofob akan berikatan dengan udara sehingga membentuk buih, kemudian dilakukan penambahan $\mathrm{HCl} 2 \mathrm{~N}$ yang bertujuan untuk menambah kepolaran sehingga gugus hidrofil akan berikatan lebih stabil dan buih yang terbentuk menjadi stabil (Kumalasari dan Sulistyani, 2011). Ekstrak etanol 50\% positif mengandung saponin karena saponin pada umumnya berada dalam bentuk glikosida sehingga cenderung bersifat polar (Padmasari dkk., 2013).

\section{Penetapan Kadar Air (Metode Gravimetri)}

Kadar air adalah suatu metode yang digunakan untuk mengetahui kandungan air yang berada di dalam sampel (Depkes RI, 2000). Prinsip kadar air dilakukan dengan metode gravimetri. Hasil kadar air yang diperoleh pada ekstrak kental daun jambu mawar dengan konsentrasi etanol $50 \%, 70 \%$ dan $90 \%$ yang sudah di rataratakan dapat dilihat pada tabel 3 .

Tabel 3. Hasil kadar air ekstrak daun jambu mawar.

\begin{tabular}{ccc}
\hline $\begin{array}{c}\text { Konsentrasi } \\
\text { Etanol }\end{array}$ & $\begin{array}{c}\text { Kadar Air } \\
(\boldsymbol{\%})\end{array}$ & $\begin{array}{c}\text { Rata-rata } \\
(\boldsymbol{\%}) \pm \mathbf{S D}\end{array}$ \\
\hline $50 \%$ & 7 & $7,67 \pm 2,08$ \\
& 10 & \\
$70 \%$ & 6 & $7,67 \pm 0,57$ \\
\hline
\end{tabular}




\begin{tabular}{lll} 
& 8 & \\
& 7 & \\
& $80 \%$ & $8,33 \pm 0,57$ \\
& 8 & \\
\hline
\end{tabular}

Tabel 3 menunjukkan bahwa ratarata kadar air yang terkandung dalam ekstrak daun jambu mawar etanol 50\% dan $70 \%$ sebesar $7,67 \%$ sedangkan ekstrak daun jambu mawar etanol 90\% sebesar 8,33\%. Hasil uji dari One Way Anova menunjukkan tidak ada perbedaan yang signifikan antar kelompok perlakuan ( $\mathrm{p}>0,05)$. Hasil uji Post Hoc Test dengan metode LSD menunjukkan semua kelompok ekstrak etanol tidak ada perbedaan signifikan ( $>>0,05)$. Menurut Voight (1994) ekstrak cair lebih dari 30\%, ekstrak kental 5-30\%, dan ekstrak kering kurang dari 5\%. Ekstrak daun jambu mawar etanol 50\%, $70 \%$ dan $90 \%$ termasuk dalam ekstrak kental. Ekstrak kental ialah sediaan yang dalam keadaan dingin dan tidak dapat dituang dan kandungan airnya berjumlah sampai 30\%. (Syamsul dkk 2016). Kandungan air yang besar dapat menyebabkan pertumbuhan mikroba karena air merupakan media pertumbuhan mikroorganisme dan juga sebagai media terjadinya reaksi enzimatis yang dapat menguraikan senyawa aktifnya (Lestari dkk 2019)

\section{SIMPULAN}

Pelarut etanol 50\%, 70\% dan 90\% memberikan perbedaan terhadap rendemen ekstrak daun jambu mawar. Hasil perhitungan rendemen ekstrak etanol jambu mawar 50\% $(23,01 \% \pm$
$0,37)$, etanol $70 \%(21,96 \% \pm 1,18)$ dan etanol $90 \%(16,57 \% \pm 0,38)$. Hasil uji One Way Anova dengan metode LSD menunjukkan terdapat perbedaan signifikan $(\mathrm{p}<0,05)$ antara kelompok etanol $90 \%$ dengan $50 \%$ dan $70 \%$.

\section{UCAPAN TERIMAKASIH}

Terima kasih kepada Sekolah Tinggi Ilmu Kesehatan Samarinda (STIKSAM) atas pendanaan pada penelitian ini.

\section{DAFTAR PUSTAKA}

Depkes RI. 2000. Parameter Standar Umum Ekstrak Tumbuhan Obat Cetakan Pertama. Jakarta: Depkes RI. Hal: 9-13.

Islam, E., Parvin,S., Raihan, O., dan Hasan, R. 2011. "In vitro and In Vivo Antioxidant Potential of Ethanolic Extract of Syzygium Jambos (L.) Bark". International Journal of Research in Ayurveda and Pharmacy. 2(3): 810-815.

Kumalasari, E., Sulistyani, N. 2011. "Aktivitas Antifungi Ekstrak Etanol Batang Binahong (Anredera cordifolia (Tenore) Steen.) Terhadap Candida albicans Serta Skrining Fitokimia”. Yogyakarta: Universitas Ahmad Dahlan. Volume: 1. Hal: 51-62

Lestari, D., Kartika, R. Marliana, E., Syamsul, E.S., 2019. Analisis Fragmentasi GC-MS Senyawa 
Aktif Antikanker Leukimia Fraksi Kloroform Umbi Bawang Tiwai (Eleutherine bulbosa (Mill.) Urb) Jurnal Ilmiah Manuntung, 5(1), eISSN. 2477-1821

Mamahit, P., Wuisan, J., Anindita, P.S. 2016. "Efektivitas Ekstrak Daun Jambu Mawar (Syzygium jambos L. Alston) Menghambat Pertumbuhan Streptococcus Mutans Secara In Vitro". Jurnal Ilmiah Farmasi. Vol 5. Hal: 5358.

Marliana, S.D., Suryanti, V., Suyono. 2005. "Skrining Fitokimia dan Analisis Kromatografi Lapis Tipis Komponen Kimia Buah Labu Siam (Sechium edule Jacq. Swartz.) Dalam Ekstrak Etanol". Surakarta: Universitas Sebelas Maret. Biofarmasi 3. Volume 1. Hal: 26-31

Mohanty, S., and Cock, E. 2010. "Bioactivity of Syzigium jambos methanolic extracs: Antibacterial activity and toxicity". Pharmacognosy Reasearch.

Volume: 2. Hal: 4-9

Morton, J.F. 1987. Malay Apple in Fruits of Warm Climates. Creative Resource System Inc. Winterville, N.C. Hal: 1

Murugan, S.S., Devi, U.P., Parameswari, K., Mani, K.R. 2011. "Antimicrobial activity of Syzigium jambos against selected human pathogen". Internasional Journal of Pharmacy and Pharmaceutical Science. Volume : 3. Issue 2. P. 1-11

Padmasari, P.D., Astuti, K.W., Warditiani, N.K. 2013. "Skrining
Fitokimia Ekstrak Etanol 70\%

Rimpang Bangle (Zingiber

purpureum Roxb.)". Jurnal

Farmasi Udayana 2 (4). Hal: 1-4

Sangi, M., Runtuwene, M.R.J., Simbala, H.E.I., Makang, V.M.A. 2008. "Analisis Fitokimia Tumbuhan Obat Di Kabupaten Minahasa Utara”. Manado: Universitas Sam Ratulangi. Chem. Prog. Volume: 1. Hal: 47-53

Supomo., Supriningrum, R., dan Junaidi, R. 2016. "Karakterisasi dan Skrining Fitokimia Daun Kerehau (Callicarpa longifolia Lamk.)". Jurnal Kimia Mulawarman. Volume 13. Hal: 89-96

Syahbirini, G. I., Batubara, T., Setiawati., dan L, Nulhakim. 2005. "Senyawa aktif daun picung (Pangium edule Reinw) sebagai insektisida botani terhadap ulat grapyak (Spodoptera litura F) (Lepidoptera noctuida)". Prosiding Simposium Nasional Kimia Bahan Alam XV. Dep.Kimia, F.MIPA, IPB-HKBA, Bogor.

Syamsul, E.S, Andani, F, Soemarie, Y.B. 2016, Uji Aktivitas analgetik ekstrak etanolik daun kerehau (Collicarpa longifolia Lamk.) pada mencit putih, Traditional Medicine Journal

Syamsul, E.S, dan Lestari, D. 2020. Metodologi Penelitian dan Statistika Farmasi (Dengan Aplikasi SPSS), Samarinda. Penerbit RV. Pustaka Horizon.

Syamsul, E.S, dan Purwanto, E.N, 2014, Uji aktivitas perasan buah 
mentimun (Cucumis sativus L) sebagai biolarvasida terhadap larva nyamuk Aedes aegypti L, Jurnal Kimia Universitas Mulawarman.

Turkmen, N., Sari, F., dan Velioglu, Y.S. 2005. "The effect of cookingmethods on total phenolics and antioxidant activity of selected green vegetables'. Food Chemistry 93:713-718

Voight, R. 1994. Buku Pelajaran Teknologi Farmasi edisi V. Yogyakarta: Universitas Gajah Mada Press. Hal: 570-571

Wardani, A.T., dan Leviana, F. 2010. "Pengaruh Cairan Penyari terhadap Rendemen dan Kadar Tanin Ekstrak Daun Jambu Biji (Psidium guajava L.)". Jurnal Farmasi Indonesia. Surakarta: Universitas Setia Budi. Volume: 7. Hal: 57-61 